\title{
Theoretical Study in Human Rights Perspective on the Private Private Vocational School of Understanding in the Dimension of Evidence in the Criminal Justice Process in Indonesia
}

\author{
H. Darmadi Djufri \\ Doctorate Candidate at Law Faculty, Borobudur University, Jakarta
}

\begin{abstract}
The principle of presumption of innocence in the criminal justice system in essence establishes the whole process of implementing criminal procedural law to be carried out in a balanced manner in accordance with the wishes of the values of Human Rights adopted in Indonesia. Therefore, in the corridor of criminal procedural law, the principle of presumption of innocence must be the main guideline in treating suspects or defendants suspected of committing a criminal act. That is, in implementing law enforcement, the human rights inherent in the suspect and the defendant must not be reduced. KUHAP itself has placed suspects or defendants in a position that must be treated in accordance with human rights values. As a fundamental principle in criminal law, the principle of presumption of innocence is closely related to the problem of proof as a process for determining and declaring one's fault. Through this process of proof, it will be determined whether the evidentiary power of any evidence alleged by the public prosecutor in his indictment will make a defendant released, released from all demands, or convicted.
\end{abstract}

Keywords: Principle of Presumption of Innocence, Human Rights Dimension, Law Enforcement.

DOI: $10.7176 / \mathrm{JLPG} / 88-07$

Publication date: August $31^{\text {st }} 2019$

\section{A. Introduction}

The issue of the presumption of innocence in relation to mass media coverage in Indonesia is not a new thing. There have been frequent discussions, both in a limited environment and in a seminar. However, there are still differences of opinion about the principle in the news by the mass media. So far the principle of presumption of innocence is considered only for and applies to activities in matters relating to the criminal justice process. So that people do not care about the principle, except if things happen that are unpleasant to him.

Lately the coverage in print and electronic media has been dominated by the rise of legal cases. Almost every day the public is presented with news that includes the involvement of important officials in the republic that we love in a cycle of corruption and money laundering. Even though it is still in the process of being examined in court, many times various media justify them as guilty people and as perpetrators of crimes, even though there has been no verdict that has been found guilty. On this side the principle of presumption of innocence becomes something that is not valuable and does not have the right to be attached to them as a right which is legally intended for them mutatis mutandis. ${ }^{1}$ The media has clearly castigated the rights of the suspect / / defendant to be found not guilty to the verdict of the judge who has permanent legal force. This is certainly not in accordance with the legal meaning mandated in the constitution.

Meanwhile, human rights are essentially the most basic rights possessed by all human beings as the highest gift from God the Almighty, wherever humans live, because with those rights humans can become dignified and civilized beings. With a human rights position that is very central in the macrocosm and the microcosm of the life of the human nation, no one or ruler can deprive or reduce basic human rights. ${ }^{2}$

Protection of human rights (HAM) is one of the main pillars of the Democratic State, in addition to the rule of law reflected in the principles of the Rule of Law. ${ }^{3}$ As a democratic country based on law (rechtstaat), it is proper for Indonesia to regulate the protection of human rights (HAM) into its constitution. Protection of human rights (HAM) is given to all people, including those who are suspected and or have been proven to commit criminal offenses. A person who is suspected of committing a crime (as a suspect or defendant) should be given

\footnotetext{
${ }^{1}$ Mutatis mutandis comes from Latin which means more or less is "important changes have been made". This term is used when comparing two situations with different variables. This term has the connotation that the reader pays attention to the differences in current statements and previous statements, even though these two statements are analogous. This term is often used in the fields of economics, philosophy and law to measure a statement with a new term. Examples of the use of this term in Indonesian legislation are found in Law Number 12 of 2011. In Article 31, it is stated, "Provisions concerning the planning of the preparation of Government Regulations as referred to in Article 24 up to Article 29 apply mutatis mutandis to the planning of drafting a Presidential Regulation . " More or less means, "The preparation of the Presidential Regulation is exactly the same as the preparation of Government Regulations.".

${ }^{2}$ Sri Hastuti Puspitasari, "Refleksi Gagasan Dan Pengaturan HAM Dalam Konstitusi Indonesia", dalam Ni'matul Huda \& Sri Hastuti Puspitasari (ed.), Kontribusi Pemikiran Untuk 50 Tahun Prof.Dr. Moh. Mahfud MD, SH. Retrospeksi Terhadap Masalah Hukum dan Kenegaraan, (Yogyakarta: FH UII Press-Pascasarjana FH UII, 2007), p. 1.

${ }^{3}$ Artidjo Alkostar, Korupsi Politik di Negara Modern, FH UII Press, Yogyakarta, 2008, p. 329
} 
or attention to his rights as a human being, because by holding a status as a suspect or accused of a criminal offense, he will be subject to certain actions which reduce his human rights. ${ }^{1}$

Indonesia is a country based on law, must uphold the legal system that guarantees legal certainty and protection of human rights. ${ }^{2}$ The state must guarantee the equality of each individual including the independence of individuals to use their human rights. This is the condition of sine quanon, given that the state of law was born as a result of individual struggle to free itself from the attachments and arbitrary actions of the authorities. ${ }^{3}$ On this basis, the authorities must not act arbitrarily against individuals and their powers must be limited. In a legal state, everyone is treated equlity before the law and is a basic element of the basic conception of human rights. As a manifestation and implementation of equal rights before the law in the provisions of criminal procedural law, there is an existence that humans must be considered innocent before being proven wrong or known as the presumption of innocence. That is, the principle of presumption of innocence is the basis of protecting human rights for a suspect and defendant from arbitrary acts of investigators, prosecutors and judges who adjudicate his case.

The application of the presumption of innocence principle puts the state in this case represented by the public prosecutor who is burdened to prove the criminal elements charged, and not the defendant who must prove his innocence. Furthermore, the judge who will decide to impose a sentence on the defendant if the evidence is limited by law and is also supported by the judge's belief in the existence of the evidence.

Regarding the process of settling criminal cases against suspects or defendants, according to Erni Widhayanti stated: In dealing with suspicions of violations of criminal law, suspects or defendants must face law enforcement giants ranging from investigators, prosecutors to judges before the court. Upright and mighty they face suspects or defendants alone, by carrying out articles, laws, legal procedures, etc. that are often not understood by suspects or defendants. Justice in him includes an element of balance from both sides balanced in all respects. So the product of justice from the justice process is only possible if both parties are balanced in all respects. Defenders and their legal knowledge and experience accompany suspects or defendants in obtaining fair decisions.

With this line of thought, proof of someone suspected of committing a crime must depart from the perspective that the person is not guilty or does not commit a criminal act suspected of him. Such a perspective is essentially an embodiment of the appreciation of the existence of humanity from people suspected of committing a criminal act. The justification that can be stated is that the existence of the presumption of innocence principle is very important both in terms of material criminal law and criminal procedure law, especially seen from the optics of human rights (HAM).

From what has been described above, the authors are interested in researching more deeply into a scientific paper writing and will try to answer the problems that the author raised in this scientific work, where the author will try to answer the problem of the extent to which the presumption of innocence in the proof dimension is used in the criminal justice process in Indonesia?

\section{B. Research methodology}

The research method is the main method used by a researcher to achieve a goal, the method is used after the research takes into account its feasibility in terms of the purpose of the research situation. This type of research is normative juridical, which is a study that starts deductively with an analysis of the articles in the legislation governing problems. Juridical legal research is intended as a type of research that refers to existing literature studies or to secondary data used, while normative research is legal research that aims to obtain normative knowledge about the relationship between one rule and other regulations and application in practice. This research is descriptive analytical, namely research to solve problems by describing the problem through collecting, compiling and analyzing data, then explained and then given an assessment. ${ }^{4}$

Research conducted using the Normative Juridical approach method. This approach is useful for approaching the problems studied using the basic legislation that applies in Indonesia. The data source of this study consists of: Primary, secondary and tertiary data sources. Primary Data Sources, Data obtained or collected by researchers directly from the data source. Primary data is also called original data or new data that has up to date properties. To obtain primary data, researchers must collect it directly. Secondary Data Sources consist of: Primary Law Materials, in the form of relevant legislation, consisting of: Law No. 8 of 1981 concerning KUHAP, Law No.48 of 2009 concerning Judicial Power, Law No.18 of 2003 concerning Advocates, Law No. 16 of 2011

\footnotetext{
${ }^{1}$ Shinta Agustina, Makalah diangkat dari Laporan Penelitian BBI tahun 2001, dan disampaikan pada Seminar tentang "Demokrasi dan HAM: Tinjauan Hukum Hak Asasi Manusia dan Perlindungannya di Indonesia" Padang, Genta Budaya, 15 Oktober 2003

${ }^{2}$ Lilik Mulyadi, Pembalikan Beban Pembuktian Tindak Pidana Korupsi, Alumni,Bandung: 2004, p.33, The rule of law is a state that stands above the law that guarantees the values of equality, freedom and justice to its citizens. As a logical consequence, the order of life in a society, nation, and state must be guided by legal norms, both written in positive law and those that live and develop in society.

${ }^{3}$ Sudargo Gautama, Pengertian Tentang Negara Hukum, Alumni, Bandung, 1983, p. 3.

${ }^{4}$ Rianto Adi, Metodologi Penelitian Sosial dan Hukum, Granit, Jakarta, 2004, p.128.
} 
concerning Legal Aid, Secondary Legal Materials, in the form of relevant literature books, Court Decisions, articles, journals, etc., Tertiary Legal Materials, in the form of legal dictionaries and encyclopedias.

\section{Discussion}

\section{HAM in the optics of the rule of law}

In the Indonesian constitution it has been determined that the country of Indonesia is a country based on law. ${ }^{1}$ This means that in the perspective of a legal state, the rule of law must be enforced consequently so that the law functions to control, supervise and limit power. The law must not be used as a political instrument of rule (law by law) to justify the actions of the authorities that harm the people and the state. Therefore, the state is the main component that must enforce the law itself. ${ }^{2}$

Thus, the essence of the rule of law is the realization of the rule of law as one of the joints in the life of society, nation and state. In this connection the law must always appear as a means that must color life, both individuals, communities, and state and government institutions. In a legal state, the position of citizens as well as government officials is the same, there is no difference before the law. But in a distinguishing function, the function of government is to regulate, while the people are regulated, both those who regulate and those who are regulated must be guided by law.

Related to the above, Sudarto Gautama stated straightforwardly and firmly that in a state law besides equality there are also restrictions (restriction). The limits of this power also change, depending on the circumstances. However, the means used to limit both interests are legal. Both countries and individuals are legal subjects who have rights and obligations. Therefore, in a legal state, the position and relationship of individuals to the state are always in balance. Both have rights and obligations that are protected by law. ${ }^{3}$

In various legal literature it is stated that one of the conditions for a legal state is the guarantee of human rights. All the conceptions of the state of law that have been put forward by thinkers about the state and law always put the idea of protecting human rights as its main characteristic. In the concept of the law state both rechstaat and rule of law, there is protection of human rights which is not only a normative requirement for the existence of a state of law, but empirically these requirements must be implemented by a state that has claimed to be a state of law. ${ }^{4}$ Legal recognition of human rights is very important for every citizen, because they are free to move without being disturbed by state officials. Likewise, state officials who commit human rights violations can be legally processed. ${ }^{5}$

Therefore, according to Moh. Mahfud MD, the recognition and protection of human rights or human rights of citizens by the constitution - both in the Preamble and Body of the 1945 Constitution - is proof that Indonesia is a country that stands on the principle of the rule of law. ${ }^{6}$ In such a concept, it is not only understood that a legal state aims to recognize and protect human rights in the sense that the state guarantees every citizen to be free in a legal environment in accordance with the provisions of the law as stated by Frederich Julius Stahl, but human rights in the legal context it must also be understood as a reality and legal awareness that lives in society that must be upheld by every individual as a norm or rule of law in the community's social relations.

Enforcement of human rights here is not merely the enforcement and implementation of regulations or laws, but in the material sense, namely law that is in accordance with and which brings social justice to the community. ${ }^{7}$ In this perspective it is evident that a country that respects human rights is a state of law in the material / substantial sense or rechstaat or rule of law. Regardless of the value or substance, the prevailing legal system becomes repressive and maintains the status quo. Only in a legal system that is responsive or accommodative can human rights be respected and developed. ${ }^{8}$

2. The Meaning and Existence of the Principle of Guilt and the Principle of the Presumption of Guilt in the

Dimension of Proof in the Perspective of Human Rights

For Satjipto Rahadjo, the law of a nation is not a collection of a large number of regulations, but a building that has character and meaning. ${ }^{9}$ Therefore, to understand the legal system as well as possible, we cannot just look at

\footnotetext{
${ }^{1}$ Article 1 paragraph (3) of the 1945 Constitution of the Republic of Indonesia. It was also found in the explanation of the pre-amendment to the 1945 Constitution which states that Indonesia is a country based on law (rechtsstaat) and not based on mere power (machtsstaat). As a logical consequence, the order of life of the people, nation and state must be guided by legal norms. see Bambang Sutiyoso \& Sri Hastuti Puspitasari, Aspek-Aspek Perkembangan Kekuasaan Kehakiman di Indonesia, UII Press, Yogyakarta, 2005, p. 9.

2 John Pieris \& Wiwik Sri Widiarty, Negara Hukum dan Perlindungan Konsumen Terhadap Produk Pangan Kadaluarsa, Pelangi Cendikia, Jakarta, 2007, p. 29

${ }^{3}$ Sudargo Gautama, loc.cit.

${ }^{4}$ Ni'matul Huda \& Sri Hastuti Puspitasari (ed.), op.cit., p. 5.

${ }^{5}$ Didit Hariadi Estiko \& Novianto M. Hantoro (ed.), Reformasi Hukum Nasional Suatu Kajian Terhadap Undang-Undang Produk Pemerintahan Transisi 1998-1999, P3I Sekjen DPR RI Jakarta, 2000, p. 105.

${ }^{6}$ Abdul Ghofur Anshori \& Sobirin Malian (ed.), Membangun Hukum Indonesia: Pidato Pengukuhan Guru Besar Ilmu Hukum, Kreasi Total Media, Yogyakarta, 2008, p. 249-250.

${ }^{7}$ Endang Sutrisno, Bunga Rampai Hukum dan Globalisasi, Genta Press, Yogyakarta, 2007, p. 177.

${ }^{8}$ Ibid., p. 172.

${ }^{9}$ Satjipto Rahardjo, Hukum dalam Jagat Ketertiban, UKI Press, Jakarta, 2006, p. 144.
} 
the legal regulations, but must dig up to the legal principles. ${ }^{1}$ It is this legal principle that gives ethical meaning to the legal regulations and legal procedures. According to Bambang Poernomo, if there are laws that cannot support a legal principle, the regulation will certainly lose itself from its legal nature. ${ }^{2}$

These legal principles are a very important and fundamental part of the law, even Satjipto Rahardjo makes those legal principles the "heart" of legal regulations. ${ }^{3}$ Romli Atmasasmita also emphasized that the absolute element of the law is the principles and rules. The power of the soul of the law lies in these two elements, that the element of the legal principle is the heart of the defense of law in society. ${ }^{4}$ The more maintained the principle of law, the stronger and meaningful the life and implementation of law in society. ${ }^{5}$ Even Bambang Poernomo emphasized that the principles of law as general legal expressions at the origin of legal awareness and moral convictions of human groups, it is proper that among groups of humans grow the principles of law that develop universally.

One of the legal principles that is very urgent and fundamental in providing direction for the operation of the criminal justice system, ${ }^{6}$ is the principle of presumption of innocence. This principle emphasizes that in every process of criminal cases for the sake of upholding the law, it must be carried out based on the presumption of innocence. The principle of presumption of innocence is a principle that has been universally valid. ${ }^{7}$ This principle is not only known in Indonesian criminal procedural law, but also adopted in international criminal law.

In the provisions of Indonesian legislation, the principle of presumption of innocence is regulated in the General Explanation number 3 letter c of the Criminal Procedure Code, Law No. 4 of 2004 concerning Judicial Power and Law No. 39 of 1999 concerning human rights. In international criminal law, this principle is regulated in the provisions of Article 66 paragraph (1) of the Rome Statute of the International Criminal Court (Rome Statute of the International Criminal Court), Article 11 paragraph (1) Universal Declaration of Human Rights, Article 40 paragraph (2b) point $\mathrm{i}$ of the Convention on the Rights of the Child (Convention on tea Rights of the Child).

Ahmad Ali in his book "Straightening the Way of Legal Reformation" describes that there are two important things from the notion of presumption of innocence. First, the principle of presumption of innocence only applies to criminal acts. Second, the principle of presumption of innocence is essentially the burden of proof where the defendant must prove that he is innocent, but that in the court proceedings, the state is represented by a public prosecutor who must prove that the defendant is indeed guilty, by proving that all elements of the crime are indicted.

According to Bambang Poernomo, criminal proceedings through the principle of presumption of innocence have a good to prioritize human rights guarantees for innocent suspects or defendants obtaining thorough and gradual legal judgments. ${ }^{8}$ Everyone must be considered innocent until their guilt is proven in a free and honest trial in public. These rights are one of the basic principles in law enforcement mandated by the Criminal Procedure Code.

Furthermore, Mardjono Reksodiputro, as quoted by Lilik Mulyadi, stated that the elements in the principle of presumption of innocence are the main principles of protecting citizens' rights through a fair process of law (due process of law) which covers at least: ${ }^{9}$

1) Protection against arbitrary acts by state officials;

2) That the court has the right to determine whether or not the defendant is wrong;

3) That the court session must be open (may not be confidential); and

4) That the suspect and defendant must be given guarantees to be able to defend themselves fully.

Furthermore, Siswanto Sunarso argues that with the presumption of innocence, in examining a suspect or defendant, then: ${ }^{10}$

1) The right of position and dignity of the suspect must be respected with reasonable treatment;

2) Examination may not make coercion against the suspect to provide an answer, moreover that acknowledgment can obscure or mislead the traces of the case being investigated; and

3) The judge must act fairly and wisely as possible, in the sense that it is not influenced by subjective elements, either directly or not with regard to the defendant's self.

In this perspective, the meaning and existence of the presumption of innocence in the criminal justice

\footnotetext{
${ }^{1}$ Satjipto Rahardjo, Ilmu Hukum, (Bandung: Citra Aditya Bakti, 2000), p. 47.

${ }^{2}$ Bambang Poernomo, Orientasi Hukum Acara Pidana Indonesia, Citra Aditya Bakti, Bandung, 2000, p. 73.

${ }^{3}$ Satjipto Rahardjo, Hukum....., op.cit., p. 123.

${ }^{4}$ O.C. Kaligis, Perlindungan Hukum atas Hak Asasi Tersangka, Terdakwa dan Terpidana, Alumni, Bandung, 2006, p. 131

${ }^{5}$ Bambang Poernomo, op.cit., p. 73.

${ }^{6}$ Andi Hamzah, Hukum Acara Pidana Indonesia, Sinar Grafika, Jakarta, 2008, p. 3.

${ }^{7}$ Bambang Poernomo, op.cit., p. 75.

${ }^{8}$ Ahmad Ali, Meluruskan Jalan Reformasi Hukum, Agatama Press Jakarta, 2004, p. 54

${ }^{9}$ Bambang Poernomo, op.cit., p. 82.

${ }^{10}$ Lilik Mulyadi, Pembalikan Beban Pembuktian Tindak Pidana Korupsi, Alumni, Bandung, 2004, p. 276
} 
system in essence establishes the whole process of implementing criminal procedural law to be implemented in a balanced manner. This is in line with the opinion of Kaligis that although the purpose of law enforcement is to maintain and protect the interests of the community, ${ }^{1}$ law enforcement must not sacrifice the rights and dignity of the suspect/ defendant. Conversely, the protection of the dignity of the suspect/ defendant must not sacrifice the interests of the community. Law enforcement officials must be able to lay down the principle of balance outlined in the Criminal Procedure Code so as not to sacrifice both interests protected by law. ${ }^{2}$

Therefore, in the corridor of criminal procedural law, the principle of presumption of innocence must be the main guideline in treating suspects or defendants suspected of committing a criminal act. That is, in implementing law enforcement, the human rights inherent in the suspect and the defendant must not be reduced. KUHAP itself has placed suspects or defendants in a position that must be treated according to the noble values of humanity.

According to Lilik Mulyadi, the study of optical principles of criminal law which has relatively developed and applied by society based on principles that have been universally applicable, has relevance to the dimension of proof in criminal law at the level of legislation and its implementation. ${ }^{3}$ In simple terms, it can be said that there is a close relationship between the principles of criminal law and the evidentiary dimension which is a criminal procedural law (formeel strafrech / strafprocesrecht). ${ }^{4}$ Thus, the principle of presumption of innocence as a fundamental principle in criminal law, is closely related to the problem of proof as a process to determine and declare someone's fault, whose application is based on the principles of respect and protection of human rights for suspects or defendants.

Therefore, it is reasonable if Adnan Paslyadja emphasized that when talking about criminal procedural law, the focus of the study is only on the dimensions of proof and protection of human rights. This is in line with Muladi's opinion, which emphasizes that if the criminal procedure as a whole is called a "filter" that will maintain a balance between state power and the protection of individual rights, the proof system is a "core filter", because it will be determined through a proof process whether the power of proof (bewijskracht) of any evidence will make a defendant freed (vrijspraak), released from all claims (onstlag van alle rechtsvervolging), or convicted. ${ }^{5}$

The obligation to provide guarantees for the protection of the rights of suspects, defendants and convicts while undergoing the criminal justice process until serving their sentence, is to become the substance of the criminal procedure law. Because the criminal procedure in its implementation emphasizes equality before the law as a manifestation of human rights, the principle of presumption of innocence should be intended as a means of justification for the entire process of implementing criminal procedure law. This means that the implementation of criminal justice must begin by placing the suspect or defendant in an innocent position. Law enforcers involved in the entire criminal proceedings must position themselves to pay more attention to the human rights aspects through proof instruments as a process of proceedings to determine and state one's mistakes.

Studied from the perspective of criminal procedure law, the evidentiary law basically exists, is born, grows, and develops in order to draw a conclusion for the judge in front of the court to declare the defendant proven or not committing a crime charged by the public prosecutor in his indictment, and finally the judge was put in place in order to impose a sentence on the defendant. The dimension of proof in criminal procedural law is carried out as a form of consistency in the principle of presumption of innocence, which by criminal law is laid down as a fundamental principle in the whole series of criminal justice as stipulated in the Criminal Procedure Code.

Article 66 of the Criminal Procedure Code explicitly states that "a suspect or defendant is not burdened with the obligation of proof", resulting in the consequence that the public prosecutor must accurately prepare evidence and evidence, if not so it will be difficult to convince the judge of the defendant's mistake. The burden of proof in the public prosecutor correlates with the principle of presumption of innocence and principle actualization does not blame oneself (non self incrimination). ${ }^{6}$ Furthermore, Article 183 of the Criminal Procedure Code which determines that the guilty or not of a defendant, the judge must pay attention to aspects: 1) the accused's mistake must be proven by at least two valid evidences; and 2) that for the two valid evidences, the judge obtained the belief that the criminal act had indeed occurred and the accused was the perpetrator. ${ }^{7}$ With the burden of proof on public prosecutors based on evidence that is limited by law and supported by judges' beliefs, it shows that the Criminal Procedure Code adheres to the burden of proof according to the law negatively. So, the punishment is based on multiple proofs, namely in the regulations of the law and in the convictions of the

\footnotetext{
${ }^{1}$ Siswanto Sunarso, Wawasan Penegakan Hukum Di Indonesia, Citra Aditya Bakti, Bandung, 2005 p. 187

${ }^{2}$ OC Kaligis, op.cit., p. 374.

${ }^{4}$ Ibid., p. 76.

${ }^{5}$ Muladi, Sistem Pembuktian Terbalik (Omkering van Bewijslast atau Reversel Burden of Proof atau Shifting Burden of Proof), Majalah Varia Peradilan, Jakarta, Juli 2001, p. 121

${ }^{6}$ Lilik Mulyadi, op.cit., p. 102.

${ }^{7}$ Andi Hamzah, op.cit., p. 251-257.
} 
judge. ${ }^{1}$ There are 4 (four) dimensions of proof theory, namely Positive Theory of Proof Based on the Law, Proof Theory Based on Judge's Beliefs Only, Proof Theory Based on Judge's Beliefs on Logical Reasons, and Negative Theory of Proof Based on Laws Negatively.

This system of proof with the burden of proof in the public prosecutor is not only adopted by continental countries, but also in Anglo-Saxon countries. According to Indriyanto Seno Adji, this is due to the universal principle wherever it still requires the presumption of human rights which cannot be reduced by anyone and for any reason (Non-Derogable Right).innocence as a principle that is acceptability in nature, so that the suspect or defendant is never charged to prove his guilt, not even obliged to blame himself (non-self incrimination) ), furthermore that the defendant has the right called "The Right to Remain Silent" (the right to remain silent). All of this is part of the principle of protection and respect for. ${ }^{2}$

However, in the Indonesian criminal justice system other than being embraced by a system of proof that is charged to the public prosecutor, it is also known as a system of proof that is charged to the defendant to prove his innocence, commonly known as the reversal of proof burden or invalid proof. In essence, the reversal of the burden of proof is a deviation from the law of proof. The principle of reversing the burden of proof in the Indonesian criminal law system is known in the Corruption Act (Law No. 31 of 1999 in conjunction with Law No. 20 of 2001), Money Laundering (Law No. 15 of 2002 in conjunction with Law No. 25 of 2003) and Consumer Protection (Law No. 8 of 1999). ${ }^{3}$ According to Andi Hamzah, there are two articles in the UUTPK, namely Article 17 and Article 18 which urge the presumption of innocence. The two articles do not show us about the adoption of a reversal of the burden of proof because the public prosecutor is still obliged to prove that the defendant has corruption. It's just that the principle principle urges that principle, because it can only strengthen the testimony of other witnesses that the accused has been corrupted.

Regarding the reversal of the burden of proof, Indriyanto Seno Adji emphasized that: ${ }^{4}$

"The principle of reversing the burden of proof is a system of proof that is beyond the theoretical norms of proof in universal Criminal Law. In Criminal Law (Formil), both continental and Anglo-Saxon systems, recognize proof by still imposing obligations on the Public Prosecutor, except that in "certain cases" (certain cases) it is permissible to apply with a different mechanism, namely Load Reversal System Proof of what is known as the "Reversal of Burden Proof" ("Omkering van Bewijslast"), is not done in an overall way, but has minimum boundaries that do not destroy a protection and appreciation of human rights, especially the rights of suspects / defendants".

Thus, Indriyanto Seno Adji wants to emphasize that the burden of reversal system of proof can only be done for certain cases and also never exist that is absolute in total, meaning that it can only be applied in a limited way, namely towards offenses relating to gratification. related to bribery. ${ }^{5}$ It must be admitted that universally it is not known to be reversed proof that is of a general nature, because this is very vulnerable to human rights violations. Therefore, according to Muladi the application of the principle of reversing the burden of proof should be carried out carefully and selectively and carried out in the context of "proceedings" or in the position of defendants. Without this kind of limitation, a reverse proof system will inevitably lead to what is called criminogenic "miscarriage of justice."

According to Akil Mochtar, this is important to note because the function of power besides having to control crime (crime control) must also protect individual rights (due process). This is related to the presumption of innocence as opposed to presumption of guilt. The regulation of criminal law must not imply panic regulation that deviates from the principles of law. Excessive attitude will actually lead to injustice (miscariage of justice) because of the occurrence of overcriminalization and open opportunities for access such as extortion (estortion) and anxiety in society. ${ }^{6}$ Therefore, to avoid this, the implementation of a system of reversing the burden of proof must be carried out or based on the acknowledgment of the principle of presumption of innocence of the accused.

Indeed, it must be admitted that studying from a human rights perspective actually reversing the burden of proof is a process that is prone to human rights violations. Then the implementation of these human rights is examined from the provisions of criminal procedural law, it is permissible to reverse the burden of proof of the wrongdoing of the perpetrators to intersect with the presumption of innocence as the principle of presumption of guilt or rather the principle of presumption of corruption. So there is a problem with shifting the presumption of innocence as the principle of presumption of guilt in reversing the burden of proof. With the adoption of the system, which contains the principle of presumption of guilt, it tends to be regarded as a denial of the presumption of innocence which has been recognized as universal principles. ${ }^{7}$

\footnotetext{
${ }^{1}$ Ibid., p. 256.

${ }^{2}$ Indriyanto Seno Adji, Korupsi Kebijakan Aparatur Negara dan Hukum Pidana, Edisi I, Diadit Media, Jakarta, 2007, p. 333.

${ }^{3}$ Lilik Mulyadi, op.cit., p. 104.

${ }^{4}$ Indriyanto Seno Adji, op.cit., p. 328

${ }^{5}$ Ibid., p. 334.

${ }^{6}$ Muladi, op.cit., p. 121-122.

${ }^{7}$ Akil Mochtar, Memberantas Korupsi: Efektivitas Sistem Pembalikan Beban Pembuktian dalam Gratifikasi, Q-Communication, Jakarta,
} 
If viewed theoretically the principle of presumption of innocence is not absolute and may be deviated, the provision can only be applied to certain cases or cases that require extraordinary handling, such as cases of corruption or money laundering. Therefore the principle of presumption of innocence cannot be opposed by the presumption of guilt. By quoting Herbert L. Packer's opinion, Lilik Mulyadi stressed that it is wrong if the principle of presumption of guilt is something that is contrary to the presumption of innocence. Even though they are two different things, they cannot be contrasted in the process of proceedings. Concretely, the principle of presumption of innocence is legal normative and not oriented towards the final result while the principle of presumption of guilt is descriptive factual so that legal proceedings must be carried out from the stage of investigation, investigation, prosecution and judicial stage.

Therefore, criminal proceedings for the sake of upholding the law can be carried out based on principles both presumption of innocence and presumption of guilt. According to Bambang Poernomo, this is because all have one point of commonality towards preventive or repressive actions against crime. He also explained that both the presumption of innocence and the principle of presumption of guilt in practice have their own aspects of evil and goodness:

"Criminal proceedings through the principle of presumption of innocence have the good to prioritize human rights guarantees for innocent suspects to obtain a thorough and gradual legal assessment. However, the procedural nature of investigation, prosecution, and final decision can be a case process that is fragmented and slow at each stage, so that covert evils allow opportunities for officers to abuse their authority which results in suppressing the human rights of every person dealing with criminal cases. Whereas, the criminal case process through the principle of presumption of guilt has goodness with the existence of a regulation on the authority of the state instrument which has determined a set of tasks to work efficiently, so that any presumption of guilt against the suspect can be proven earlier and correctly. Failure or error in carrying out actions for the case process based on the principle of presumption of guilt is a risk that the officer concerned will be prosecuted according to the law with the ultimate goal of protecting the human rights of every person dealing with criminal cases. However, in criminal proceedings that emphasize work efficiency, allowing deterioration to occur is a method of examination that is closed and which is continued by formal formal proceedings which will reduce social control which can result in reducing the rights of suspects ".

Furthermore, Ahmad Ali emphasized that the application of the presumption of innocence principle began in the courtroom (inside court room). In other words, in the police duties that are still in effect the presumption of innocence is because it is very illogical to say that the police arrested and detained a suspect on the basis of alleged innocence. The truth is that the police arrested and detained a suspect because the person was allegedly guilty. But even so because everyone has human rights to be tried by a fair trial process, the public prosecutor representing the state is liable to prove wrong, and if the public prosecutor fails to prove it, the defendant must be declared totally unproblematic. Only a judge's verdict that has legal force remains the one who can impose a sentence against him. Therefore, do not confuse the application of the presumption of presumption of innocence on the one hand with the application of the principle of fair trial which is a human right of every human being.

At first glance, there seems to be a contradiction between the principle of presumption of innocence and the application of the principle of proof, but according to Ahmad Ali the two principles are not really in conflict. For him, the most essential problem in the principle of the presumption of innocence is that no one can be subject to criminal sanctions, unless given the opportunity to prove his innocence. When the principle of presumption of innocence was imposed, at first the public prosecutor who had to be burdened to prove the elements of the crime he was charged with, and the defendant could deny it by defending the indictment. On the contrary in the principle of proof reversed, the defendant must prove his innocence. The second equation of the principle is that both of them still gave the defendant the opportunity to defend. The defendant's human rights to defend himself are still guaranteed, both in the principle of presumption of innocence and in the principle of reversing the burden of proof.

With this reality, the application of this system of reversing the burden of proof and its relevance to the principle of presumption of innocence is not a matter of concern in the criminal justice system. In fact, according to Indriyanto Seno Adji the application of the system of reversing the burden of proof is an unavoidable reality, especially the minimization of the rights of the "dader" (suspect / defendant) relating to the principle of non-selfincrimination and presumption of innocence. However, the minimization of these rights is greatly avoided by the elimination of these rights, and if this happens, it is said that the system of reversing the burden of proof is the potential for human rights violations.

On the basis of the above thoughts, in order to anticipate the negative excesses of the reversal system of proof that actually has the potential to violate human rights, the application of proof reversal systems to prove the wrongdoers / makers must be balanced and proportionate between the protection of individual independence and the deprivation of rights individual actors on the other side. This means that the implementation of proof of 
guilt or not against the maker in the judicial process must be carried out on the basis of the presumption of innocence as a fundamental principle that has been universally recognized.

Putting the principle of presumption of innocence in every stage of the implementation of the Criminal Procedure Code will guarantee the recognition of equality before the law. Although this principle can be deviated, in the implementation of the evidence it must always place suspects / defendants on their human values that cannot be seized by anyone including the state even if without a clear basis. This is where the relevance lies between the principle of presumption of innocence and the dimension of proof, whose application is based on the recognition and appreciation of human rights values.

\section{Closing}

The principle of presumption of innocence in the criminal justice system in essence establishes the whole process of implementing criminal procedural law to be implemented in a balanced manner. Therefore, in the corridor of criminal procedural law, the principle of presumption of innocence must be the main guideline in treating suspects or defendants suspected of committing a criminal act. That is, in implementing law enforcement, the human rights inherent in the suspect and the defendant must not be reduced. KUHAP itself has placed suspects or defendants in a position that must be treated in accordance with human rights values. As a fundamental principle in criminal law, the principle of presumption of innocence is closely related to the problem of proof as a process for determining and declaring one's fault. Through this process of proof, it will be determined whether the evidentiary power of any evidence alleged by the public prosecutor in his indictment will make a defendant released, released from all demands, or convicted.

In the Indonesian criminal justice system, besides being embraced a system of proof that is charged to the public prosecutor, it is also known as a system of proof that is charged to the defendant to prove his innocence, commonly known as the reversal of proof burden or invalid proof. It is permissible to reverse the burden of proof of the wrongdoing of the perpetrators who will intersect with the principle of presumption of innocence as the principle of presumption of guilt, so that it is very vulnerable to human rights violations. Therefore, the application of the reversal of the burden of proof should be carried out carefully and selectively and carried out in the position of the defendant, so that it can only be applied to certain cases and can only be applied in a limited way, namely to offenses relating to bribery. In addition, in order to anticipate the negative excesses of the system of reversing the burden of proof that actually has the potential to violate human rights, the implementation must be carried out in a balanced and proportionate manner between the protection of individual independence and the seizure of the individual rights of the perpetrator on the other.

Thus, the principle of presumption of innocence is basically not absolute and may be deviated, with provisions that can only be applied to certain cases or cases that require extraordinary handling. Therefore the presumption of innocence cannot be opposed by the presumption of guilt. The process of criminal cases for the sake of upholding the law can be carried out based on the principles of both presumption of innocence and presumption of guilt, provided that it must be carried out while paying attention to one's human rights.

\section{References}

Abdul Ghofur Anshori \& Sobirin Malian (ed.), Membangun Hukum Indonesia : Pidato Pengukuhan Guru Besar Ilmu Hukum, Kreasi Total Media, Yogyakarta, 2008.

Ahmad Ali, Meluruskan Jalan Reformasi Hukum, Agatama Press, Jakarta, 2004.

-----------, Keterpurukan Hukum di Indonesia (Penyebab dan Solusinya), Ghalia Indonesia, Jakarta, 2005.

Akil Mochtar, Memberantas Korupsi : Efektivitas Sistem Pembalikan Beban Pembuktian dalam Gratifikasi, QCommunication, Jakarta, 2006.

Andi Hamzah, Hukum Acara Pidana Indonesia, Sinar Grafika, Jakarta, 2008.

Artidjo Alkostar, Korupsi Politik di Negara Modern, FH UII Press, Yogyakarta, 2008.

Bambang Poernomo, Orientasi Hukum Acara Pidana Indonesia, Citra Aditya Bakti, Bandung, 2000.

Bambang Sutiyoso \& Sri Hastuti Puspitasari, Aspek-Aspek Perkembangan Kekuasaan Kehakiman di Indonesia, UII Press, Yogyakarta, 2005.

Didit Hariadi Estiko \& Novianto M. Hantoro (ed.), Reformasi Hukum Nasional Suatu Kajian Terhadap UndangUndang Produk Pemerintahan Transisi 1998-1999, P3I Sekjen DPR RI, Jakarta, 2000.

Dwi Putri Cahyati, Diktat Kuliah Hukum dan Hak Asasi Manusia, FH UMJ, Jakarta, 2007.

Endang Sutrisno, Bunga Rampai Hukum dan Globalisasi, Genta Press, Yogyakarta, 2007.

Frans Magnis-Suseno, Etika Politik: Prinsip-Prinsip Moral Dasar Kenegaraan Modern, Gramedia Pustaka Utama, Jakarta, 1999.

Indriyanto Seno Adji, Korupsi Kebijakan Aparatur Negara dan Hukum Pidana, Edisi I, Diadit Media, Jakarta, 2007.

Iriyanto A. Baso Ence, Negara Hukum dan Hak Uji Konstitusionalitas Mahkamah Konstitusi, Alumni, Bandung, 2008. 
John Pieris \& Wiwik Sri Widiarty, Negara Hukum dan Perlindungan Konsumen Terhadap Produk Pangan Kadaluarsa, Pelangi Cendikia, Jakarta, 2007.

Lilik Mulyadi, Pembalikan Beban Pembuktian Tindak Pidana Korupsi, Alumni, Bandung, 2004.

Moh. Mahfud MD., Perdebatan Hukum Tata Negara Pasca Amandemen Konstitusi, LP3ES, Jakarta, 2007.

Muladi, Sistem Pembuktian Terbalik (Omkering van Bewijslast atau Reversel Burden of Proof atau Shifting Burden of Proof), Majalah Varia Peradilan, Jakarta, Juli 2001.

Ni'matul Huda \& Sri Hastuti Puspitasari (ed.), Kontribusi Pemikiran Untuk 50 Tahun Prof.Dr. Moh. Mahfud MD, SH. Retrospeksi Terhadap Masalah Hukum dan Kenegaraan, FH UII Press-Pascasarjana FH UII, Yogyakarta, 2007.

OC Kaligis, Perlindungan Hukum atas Hak Asasi Tersangka, Terdakwa dan Terpidana, Alumni, Bandung, 2006. Satjipto Rahardjo, Hukum dalam Jagat Ketertiban, UKI Press, Jakarta, 2006.

, Ilmu Hukum, Citra Aditya Bakti, Bandung, 2000.

Siswanto Sunarso, Wawasan Penegakan Hukum Di Indonesia, Citra Aditya Bakti, Bandung, 2005.

Sudargo Gautama, Pengertian Tentang Negara Hukum, Alumni, Bandung, 1983. 